\title{
FDA CDRH GUDID Terminology
}

National Cancer Institute

\section{Source}

National Cancer Institute. FDA CDRH GUDID Terminology. NCI Thesaurus. Code C106039.

A set of terminology created to support the efforts of the FDA CDRH Global Unique Device Identification Database project. 